\title{
JUBILEUSZOWA SESJA: \\ 60. LAT OŚRODKA ARCHIWÓW, BIBLIOTEK I MUZEÓW \\ KOŚCIELNYCH KATOLICKIEGO UNIWERSYTETU LUBELSKIEGO JANA PAWLA II. DOROBEK I PERSPEKTYWY, LUBLIN 14 XI 2016
}

W 2016 r. Ośrodek Archiwów Bibliotek i Muzeów Kościelnych świętował 60. lat swojej działalności. Jubileusz ten był inspiracją do spotkania się środowiska naukowego w Lublinie, w dniu 14 listopada 2016 r., aby podsumować dotychczasową działalność Ośrodka oraz przedstawić nowe perspektywy badawcze.

Jubileusz Ośrodka ABMK został zainaugurowany poranną mszą św. koncelebrowaną w kościele akademickim KUL, w intencji zmarłych i żyjących pracowników Ośrodka ABMK. W swojej homilii biskup pomocniczy diecezji zamojsko-lubaczowskiej dr hab. Mariusz Leszczyński, wspominając swoje studia w Instytucie Historii Kościoła KUL, przywołał postacie księży profesorów, którzy byli jego mistrzami: Bolesława Kumora, Stanisława Librowskiego oraz Marka T. Zahajkiewicza. Wspomniani profesorowie byli związani również z Ośrodkiem ABMK, kierując tą instytucją lub też wyznaczając kierunki jej działalności.

Druga część jubileuszowej sesji odbyła się w Czytelni Filozoficzno-Teologicznej Biblioteki Uniwersyteckiej KUL przy ul. Chopina 27. Miejsce obrad było symboliczne gdyż od 29 lutego 2016 r. wspomniana czytelnia nosi imię o. Romualda Gustawa OFM, dyrektora Biblioteki KUL (1950-1976), a także założyciela Ośrodka Archiwów Bibliotek i Muzeów Kościelnych i współzałożyciela pisma „Archiwa Biblioteki i Muzea Kościelne”.

Obrady otworzył dyrektor Ośrodka ABMK ks. dr hab. Waldemar W. Żurek SDB, prof. KUL oraz dyrektor Biblioteki Uniwersyteckiej KUL mgr Barbara Zezula. W swoich krótkich przemówieniach przypomnieli wspólne początki Ośrodka ABMK jako działu Biblioteki KUL. Zarówno dyrektor Ośrodka jak i dyrektor Książnicy KUL podkreślili bardzo owocną współpracę tych dwóch instytucji, wyrażającą się m.in. w organizacji wspólnych sesji naukowych. Jak obydwoje podkreślili ,wspólna przeszłość zobowiązuje”.

Motywem przewodnim jubileuszowej sesji były badania naukowe dotyczące dziejów Kościoła katolickiego na Kresach Wschodnich Rzeczpospolitej. 
Związane jest to $\mathrm{z}$ dużym zaangażowaniem Ośrodka ABMK w ten kierunek badań naukowych. Warto wspomnieć, że pracownicy ABMK wydali liczne monografie dotyczące dziejów Kościoła katolickiego na wspomnianych terenach, a także wykazy metrykalne z ksiąg parafialnych diecezji łuckiej i pińskiej.

Uzupełnieniem tematyki wschodniej były wystąpienia prelegentów z rzymskiego ośrodka naukowego. Należy podkreślić, że pierwszy kierownik Ośrodka ABMK, ks. Eugeniusz Reczek SI, przeniósł ideę Ośrodka do Rzymu, gdzie w roku 1958 powołał do istnienia Instytut Studiów Kościelnych (od 1970 r. Papieski), działający do dnia dzisiejszego.

Inaugurujący referat Ośrodek Archiwów Bibliotek i Muzeów Kościelnych na przestrzeni w 60 lat działalności, wygłosił dyrektor Ośrodka ABMK ks. dr hab. Waldemar W. Żurek SDB, prof. KUL. Przedstawił on historię Ośrodka ABMK, powstałego w 1956 r. jako dział Biblioteki Uniwersyteckiej KUL. W 1959 r. Ośrodek został przekształcony na międzywydziałowy zakład naukowo-badawczy. W 2009 r. Ośrodek włączono w struktury Wydziału Teologii KUL. Zgodnie ze swoim statutem Ośrodek pełni rolę łącznika między kościelnymi archiwami, bibliotekami i muzeami oraz pomaga praconikom tych instytucji w merytorycznym opracowaniu zbiorów. Ośrodek ABMK organizuje również kursy i sesje naukowe dla archiwistów, bibliotekarzy i muzealników kościelnych. Od 1959 r. Ośrodek ABMK wydaje półrocznik „Archiwa Biblioteki i Muzea Kościelne”, który jest jedynym tego typu pismem naukowym w Polsce. Współzałożycielem pisma (wraz o. R. Gustawem) i długoletnim redaktorem był ks. S. Librowski, który nadał pismu wysoki poziom naukowy. Z Ośrodkiem związani byli znani księża historycy Kościoła, m.in. Bolesław Kumor, Stanisław Librowski, Zygmunt Zieliński, Marek. T. Zahajkiewicz, Anzelm Weiss.

Drugi referat Moja droga do Kościoła, był autorstwa bpa Witalija Skomorowskiego, ordynariusza diecezji łuckiej i administratora diecezji kijowsko-żytomierskiej. Hierarcha urodzony w Berdyczowie, przedstawił sytuację katolików w Związku Sowieckim po II wojnie światowej. Na tle ogólnego losu ludzi wierzących na ziemi berdyczowskiej, wśród których było bardzo dużo Polaków, opowiedział historię swojego życia: dzieciństwo i przekazywanie wiary w domu, szykany w szkole z powodu chodzenia do kościoła, odkrycie powołania kapłańskiego, studia seminaryjne oraz praca duszpasterska po święceniach kapłańskich.

Następne wystąpienie Wspótpraca Papieskiego Instytutu Studiów Kościelnych $w$ Rzymie $z$ instytucjami $w$ Polsce, było autorstwa ks. Hieronima Fokcińskiego SI z Rzymu. Z powodu nieobecności prelegenta z przyczyn zdrowotnych, referat został odczytany. Autor wystąpienia omówił genezę powstania Instytutu Studiów Kościelnych w Rzymie, założonego przez pierwszego kierownika Ośrodka ABMK, ks. E. Reczka SI. Placówka powstała z inspiracji kard. S. Wyszyńskiego. Do jej głównych zadań należy rejestracja poloników z zbiorach zagranicznych, zwłaszcza watykańskich, ich rejestracja, opracowanie (mikrofilmowanie) i udostępnienie naukowcom w kraju. Papieski Instytut Studiów Kościelnych posiada czytelnię zbiorów, bibliotekę, organizuje konferencje, prelekcje i wystawy. Wydaje również publikacje naukowe. Od początku istnienia współpracuje z wieloma środowiskami naukowymi w Polsce oraz zagranicznymi. Od 
1976 r. przy ul. Rakowieckiej 61 w Warszawie, przy jezuickim Wydziale Teologicznym, działa punkt konsultacyjny ISK z Rzymu, udostępniający źródła archiwalne (m.in. mikrofilmy, fotografie), repertoriów, katalogów i kartotek, informacji naukowej oraz pośredniczący w nawiązywaniu kontaktów i w różnorodnych formach wymiany.

Pierwszą część sesji zakończył ks. dr Wacław Umiński CM, z referatem Troska o źródta historyczne na łamach czasopism „Archiwa Biblioteki i Muzea Kościelne” oraz „Nasza Przeszłość”. Prelegent krótko przedstawił genezę powstania półroczników „Nasza Przeszłość” (1946-) oraz „Archiwa Biblioteki i Muzea Kościelne" (1959-). Scharakteryzował również założenia programowe pism, by następnie zestawić artykuły, które ukazały się na łamach wspomnianych periodyków, grupując je i przedstawiając najbardziej istotne z nich. Na koniec ks. W. Umiński stwierdził, że wspomniane półroczniki są najważniejszymi wydawnictwami źródeł do dziejów Kościoła katolickiego w Polsce.

Drugą część sesji, otworzył referat URBE: Sieć Rzymskiej Unii Bibliotek Kościelnych - 25 lat wspótpracy autorstwa ks. Marka A. Rostkowski OMI z Rzymu. Tekst wystąpienia został odczytany, gdyż prelegent nie mógł przybyć na konferencję. W referacie ks. Rostkowski przedstawił genezę powstania sieci unii kościelnych książnic w Rzymie. Opisał również historię poszczególnych bibliotek i scharakteryzował ich zasób. Sieć URBE posiada katalog rejestrujący łącznie 3.500.000 woluminów, w tym 300 inkunabułów. Katalog jest dostępny dla czytelników na stronie internetowej: www.urbe.it Sieć stanowi wzór organizacyjny dla polskich bibliotek kościelnych, z którego doświadczenia stale korzystają poszczególne książnice.

Ks. Stanisław Zimniak SDB z Rzymu, przedstawił referat Associazione Cultori di storia Salesiana w stużbie promocji badań nad działalnościa salezjańska $w$ świecie. W swoim wystąpieniu, wspomaganym przez prezentację multimedialną, omówił historię założenia przez św. Jana Bosco w 1874 r. Zgromadzenia Salezjańskiego czyli Towarzystwa św. Franciszka Salezego. Prelegent wskazał na najważniejsze cele działalności zgromadzenia oraz realizowany charyzmat duszpasterskiej pracy z młodzieżą. Następnie ks. S. Zimniak skupił się na prowadzonych badaniach nad historią zgromadzenia, które działa na wszystkich kontynentach. Instytucją powołaną do dokumentacji i opracowywania dziejów salezjanów jest Associazione Cultori di storia Salesiana, które ma współpracowników w każdym kraju, w którym pracują duchowi synowie św. Jana Bosko. Prelegent omówił również najważniejsze wydawnictwa dotyczące przeszłości Zgromadzenia Salezjańskiego, które ukazały się dzięki działalności wspomnianej salezjańskiej placówki badawczej.

Kolejnym prelegentem był ks. Josif Vitold Kovaliv (Józef Witold Kowalów) z Ostroga w diecezji łuckiej, który przedstawił referat: Czasopiśmiennictwo katolickie na Ukrainie w okresie jej niepodległości. Ks. Józef Witold Kowalów, od kilkunastu lat pracuje jako duszpasterz w Ostrogu, w diecezji łuckiej na terenie obecnej Ukrainy. Prelegent, oprócz pracy duszpasterskiej, wydaje również pismo społeczno-religijne „Wołanie z Wołynia”. Podzielił się on ze zgromadzonymi na sesji swoim doświadczeniem pracy kapłańskiej na Ukrainie. Przedstawił historię 
działalności wydawniczej Kościoła katolickiego na Ukrainie, od momentu odrodzenia się struktur kościelnych po upadku ZSRR. Wymienił najważniejsze ukraińskie religijne periodyki, wydawnictwa naukowe, audycje radiowe i telewizyjne oraz strony internetowe. Ks. J. Kowalów wskazał również na wyzwania stojące przed ruchem wydawniczym Kościoła katolickiego na Ukrainie, w zmieniających się realiach społeczno-politycznych tego państwa.

Ks. Andrzej Szczupał CSsR z Grodna, przedstawił referat Wpływ głównych ośrodków formacyjnych diecezji grodzieńskiej na kształtowanie się dojrzałości chrześcijańskiej Kościoła partykularnego. Autor, profesor Wyższego Seminarium Diecezji Grodzieńskiej, przypomniał historię Kościoła katolickiego na terenie dzisiejszej Białorusi, sięgający chrztu Litwy w roku 1387, czasów Rzeczpospolitej Obojga Narodów, zaboru rosyjskiego, II Rzeczpospolitej, okupacji sowieckiej i niemieckiej. Powstanie Białoruskiej Socjalistycznej Republiki Sowieckiej, oznaczało likwidację struktur administracyjnych Kościoła katolickiego oraz prześladowania wiernych. Dopiero po upadku ZSRR w 1991 r. doszło do reaktywacji struktur kościelnych na Białorusi. Ks. A. Szczupał przedstawił aktualną działalność duszpasterską prowadzoną przez duchowieństwo diecezjalne i zgromadzenia zakonne na Białorusi. Szczególną uwagę prelegent zwrócił na diecezję grodzieńską, którą zamieszkuje największa liczba katolików na Białorusi, w większości Polacy. W Grodnie działa od 1990 r. Wyższe Seminarium Duchowne, wydawnictwo diecezjalne, Caritas oraz inne organizacje i instytucje kościelne.

Jubileuszową sesję zakończył referatem Dziatalność wydawnicza Ośrodka Archiwów Bibliotek i Muzeów Kościelnych dr Artur Hamryszczak, redaktor półrocznika „Archiwa Biblioteki i Muzea Kościelne”. Prelegent przedstawił genezę powstania pisma, jako organu wydawniczego Ośrodka ABMK, którego pierwszy numer ukazał się w 1959 r. Przypomniane zostały osoby redaktorów, szczególnie współzałożyciela i długoletniego (do tomu 60 ABMK) redaktora naczelnego pisma, ks. Stanisława Librowskiego, który nadał periodykowi wysoki poziom merytoryczny. A. Hamryszczak scharakteryzował również zawartość poszczególnych tomów ABMK oraz wspomniał o bazach indeksacyjnych, w których jest umieszczone pismo. Oprócz półrocznika, od 2002 r. Ośrodek ABMK wydaje serię „Biblioteka Ośrodka Archiwów Bibliotek i Muzeów Kościelnych”. Do 2016 r. ukazało się 41 pozycji książkowych. Autorami publikacji ukazujących się w ramach serii są pracownicy i współpracownicy Ośrodka ABMK.

Po zakończonych obradach uczestnicy jubileuszowej sesji podejmowali w dyskusji wybrane wątki z poszczególnych wystąpień. Wspominano wydarzenia, konferencje i kursy organizowane w przeszłości przez Ośrodek ABMK. Dzielono się informacjami o osobach będąch symbolami Ośrodka: ks. S. Librowskim, ks. B. Kumorze, ks. Marku T. Zahajkiewiczu. Uczestnicy sesji próbowali również podsumować dotychczasową działalność Ośrodka i jego osiągnięcia.

Teksty wszystkich wystąpień ukazały się w $2017 \mathrm{r}$. w publikacji pod red. ks. Waldemara W. Żurka SDB: Dawniej i dziś. Ośrodek Archiwów Bibliotek i Muzeów Kościelnych w Katolickim Uniwersytecie Lubelskim Jana Pawta II w 60-ta rocznice powstania, Lublin 2017, ss. 234. 